УДК 539.3; 624.073.4

\title{
IMPACT OF ENGINEERING/TECHNOLOGY FACTORS AND NONSTATIONARY LOADS ON THE STRESS - STRAIN STATE OF A THREE-LAYER CYLINDRICAL SHELL
}

\author{
V.V. Gaidaichuk, \\ Doctor in Engineering Science \\ K.E. Kotenko, \\ $\mathrm{Ph} . \mathrm{D}$. in Engineering Science \\ N.A. Snizhko, \\ Ph.D. in Engineering Science \\ Kyiv National University of Construction and Architecture, \\ 31 Povitroflotskyi ave., Kyiv 03680
}

DOI: $10.32347 / 2410-2547.2021 .107 .281-287$

\begin{abstract}
The article presents the assessment results of a three-layer cylindrical shell stress-strain state provided the different parameters of physical and mechanical characteristics of polymeric filler reinforced by stiffening ribs. Impact rate on the stress-strain state of the polymeric filler reinforcement due to the involvement of the discrete stiffening ribs has been determined.

Key words: three-layer cylindrical shell, stress-strain state, polymer filler, stiffening ribs, axisymmetric pulse load, finite element model.
\end{abstract}

Introduction. Problem statement. Layered shells are widely used in mechanical engineering, nuclear energy, aircraft construction, defense and other fields of technology. Their specific features allow to decrease the specific quantity of metal per strucrure, increase efficiency, ensure reliability etc. Works by P.Z. Luhovoy, V.M. Meysh and some other authors, as well as operational practice of concerned facilities witness that the structures themselves, or their separate elements exist under the conditions of periodic dynamic loads, which in most cases are of the impulse nature.

Investigation of the stress-strain state of layered shells evidence its dependence on the shell type, on its structural features, physical and mechanical characteristics of the material etc. Therefore information, which is characteristic of the importance of such dependencies and which demonstrates the character and extent of their impact on the stress-strain state of the layered structures can considerably contribute to the early optimal decision-taking.

Nevertheless, the diversity of the layered shells', numerous natural and engineering impacts on them, the restricted nature of the regulatory and calculation basis, as well as peculiarities of the stress-strain state calculations are limiting such information acquisition. With regard to that, the investigations described below are aimed at amending the theoretical aspects of the problem with practical rationale, which would illustrate the character and importance of impact on the stress-strain state of engineering solutions, operational and natural factors, physical and mechanical properties of structural materials etc. 
Investigation and analysis of investigation results. A three-layer cylindrical shell with the permanently fixed edges, a structural element of which is presented on Figure 1, has been used as a basic structure for investigations. Its geometric parameters had the following values: $L=250 \mathrm{~mm} ; R=200 \mathrm{~mm}$, $h_{1}=h_{3}=10 \mathrm{~mm}, h_{2}=60 \mathrm{~mm}$. Physical and mechanical characteristics were accordingly: $E_{1}=E_{3}=70 \mathrm{GPa}, E_{T}=0.14$ and $1.4 \mathrm{GPa}, \mu_{1}=\mu_{3}=0.3, \rho_{1}=\rho_{3}=$ $2.7^{*} 10^{3} \mathrm{~kg} / \mathrm{m}^{3}$. The shell has been loaded with the axisymmetrical internal impulse load, the distribution parameters $Q$ of which have been set up as below:

$$
Q(t)=A^{*} \sin \frac{\pi * t}{T}
$$

where: $A$ is the amplitude of the pulse power load height; $T$-load duration; $t-$ time duration.

The following loading parameters have been accepted: $A=10^{6} \mathrm{~Pa} ; T=50 * 10^{-6} \mathrm{~s}$.

Parameters of the stress-strain state have been identified through the finite element model, which included 8000 solid finite elements and 9360 nodes. The calculating software Nastran has performed calculations. Choice of the type of the solid finite element was due to obtaining more detailed and precise calculation results.

The power load amplitude was $A=10^{6} \mathrm{~Pa}$; The displacements and stresses values have been calculated through an algorithm of a direct transient dynamic process within the time interval $0 \leq t \leq 10 T$. The time interval was $0.25 \cdot 10^{-6} \mathrm{~s}$, and the total number of steps was 200 . Investigation results for cases without the polymeric filler reinforcement [1] evidence the considerable impact on the stress-strain state of physical and mechanical characteristics of namely the filler and the internal and external coating variation.

A «mechanical effect» caused by reinforcement of polymeric filler with discrete (stiffening) ribs can be an essential factor impacting the stress-strain state. Such approach to enhancing the layered structures' rigidness is getting widespread and is especially applied in the three-layered shells, demonstrating a relative unsophistication of engineering and process solutions.

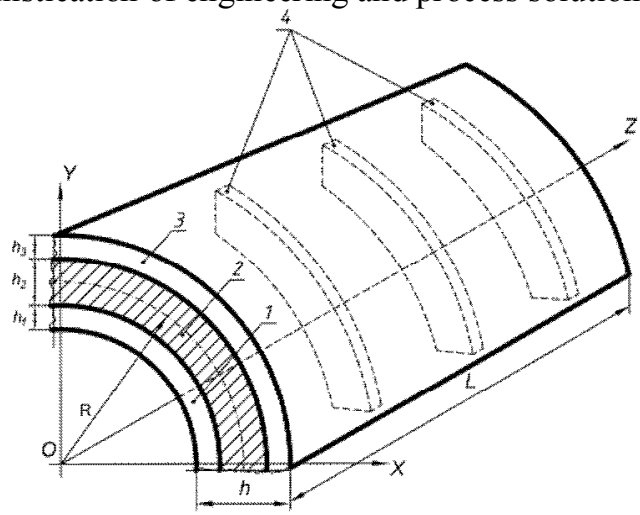

Fig. 1. Design of the three-layer shell:

1 - internal layer; 2 - filler; 3 - external layer; 4 - reinforcing ribs 
The reinforcement efficiency for the structures of this type has been determined by means of the finite-element simulation of the three-layer cylindrical shell with the circumferential reinforcement ribs, stiffly binding internal and external shell layers (Fig. 1).

Table 1

Maximal axial horizontal displacements $T_{y}$ of the shell layers with different layers' structure and different physical and mechanical properties of polymeric filler over the time interval $(t)$

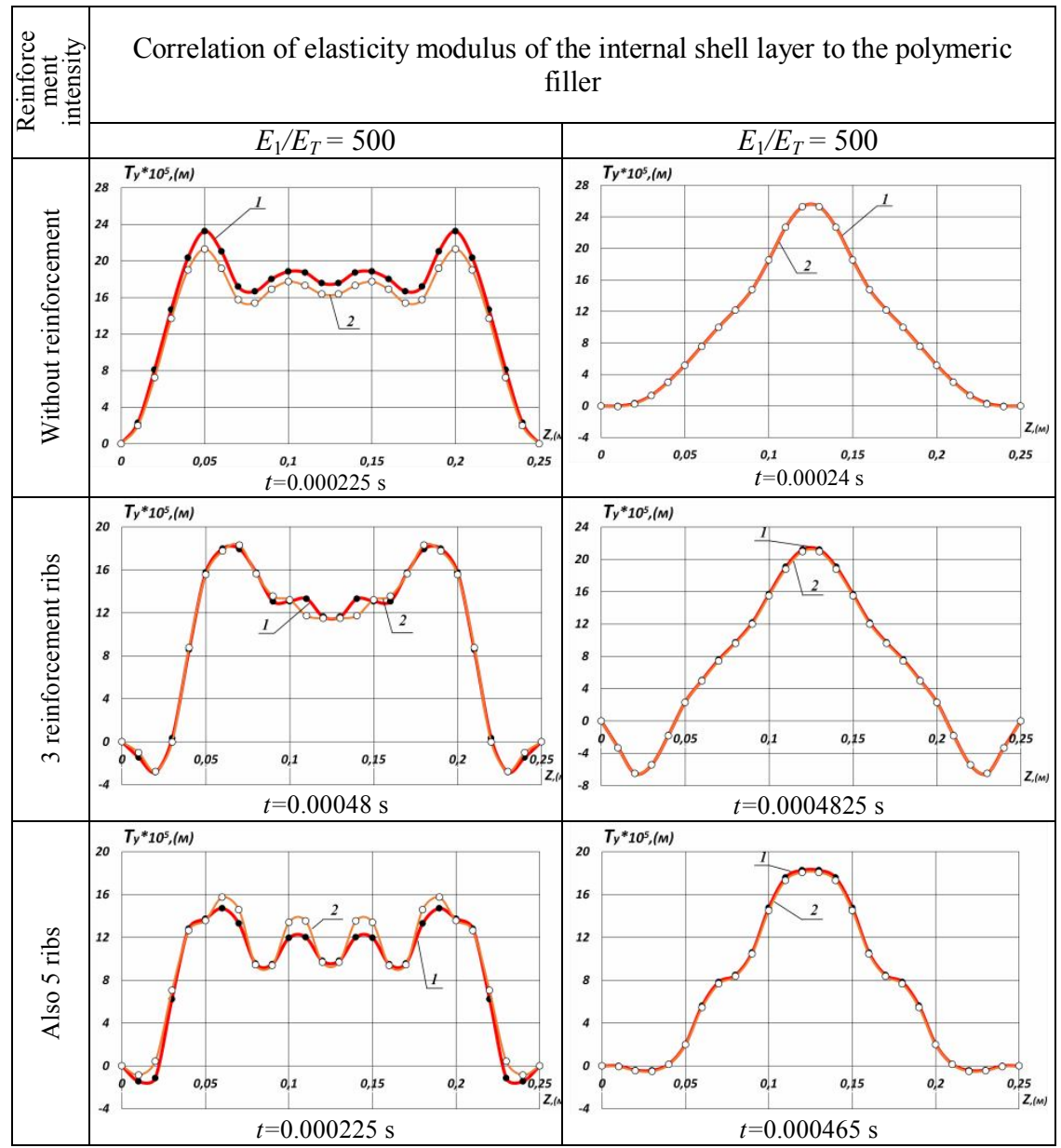

1 - internal shell layer; 2 - also external

Options with three and five reinforcement rings have been considered; rings had to be evenly distributed over the shell length. In first case, distance between rings was $0.06 \mathrm{~m}$, and in second case $0.04 \mathrm{~m}$. Values of horizontal displacements $\left(T_{y 1}\right.$ and $T_{y 2}$ ) for each reinforcement scheme have been determined through separately created finite-element models of each design variant. The layered 
shell wall structure corresponded to the correlation $h_{1}=h_{3} / h_{2}=1 / 6$, other power, geometric and physical and mechanical characteristics met the above parameters. Calculations have been performed for options $E_{1,3} / E_{T}=50$ and $E_{1,3} / E_{T}=500$. The resulting patterns (Tab. 1) show that the horizontal displacements of both bearing layers appeared to be unidirectional and have equal absolute values with amounts reaching their maximum at the same time moments. When the reinforcement is armored $E_{1,3} / E_{T}=500$ with three armoring rings, the maximal displacement has decreased by $21 \%$, with five rings - by $39 \%$. Provided the correlation $E_{1,3} / E_{T}=50$, horizontal displacements are distributed along the shell length more uneven.

They remain unidirectional and equal in values, however reach their maximum only in the center of the shell length. The more intense reinforcement (five rings instead of three) narrows the segment of maximal displacements at $E_{1,3} / E_{T}=50$ to almost $1 / 3$ of the shell length.

The maximal value of displacements within this range in relation to the non-reinforced shell has decreased by almost $15 \%$ in case of three reinforcement ribs and by almost $30 \%$ in case of five ribs.

The three-layer cylindrical shell was used for the above investigations; the diameter of the cylindrical shell outreaches its length. When the shel wall thickness and length increase, decrease of the reinforcement rings impact is observed, the deformation picture has a different nature. Thus, provided the dimensions $D=240 \mathrm{~mm}, L=400 \mathrm{~mm}, h_{1}=h_{3}=10 \mathrm{~mm}$ and $h_{2}=10 \mathrm{~mm}$ and the distances between five reinforcement rings $60 \mathrm{~mm}$, absolute value of horizontal axial displacements in the median surface of the polymeric filler structure's external layer $E_{1,3} / E_{T}=500$ reaches $0.25 \mathrm{~mm}$, and displacement of external and internal layers became contra-directional [2].

A high-standard picture of distribution of the normal stresses along the shell length (Fig. 2) shows that their values reach the maximum value at the moment of time $9.3 T(t=0.000465 \mathrm{~s})$ provided the reinforcement of polymeric filler $E_{1,3} / E_{T}=50$ with three discrete ribs. The more intense reinforcement of the filler ( 5 reinforcement rings instead of 3 ) has decreased the maximal stresses by almost $12.5 \%$.

In all cases investigated, the external sheeting layer of the shell appeared more stressed, independent on the physical and mechanical characteristics of the filler or intensity of its reinforcement.

The obtained data correlate with the conclusions of other authors [3-5] and contribute to solving some practical issues.

Conclusions. Optimization of the design and engineering decisions regarding the layered shells envisaged for operating under the nonstationary loads, increases their reliability and decreases the specific quantity of metal per structure. Application of the polymeric filler, which ensures the ratio $E_{1,3} / E_{T}=$ 50 and intensity of its reinforcement, decreases displacements of the external shell layers by over $30 \%$. 


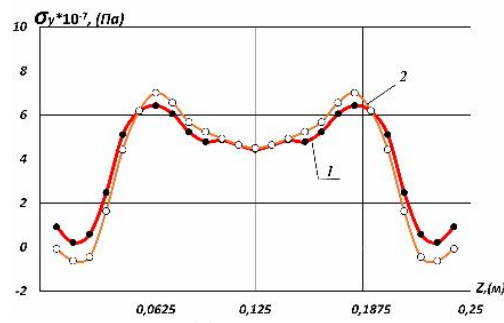

(a) $t=0.00048 \mathrm{~s}$

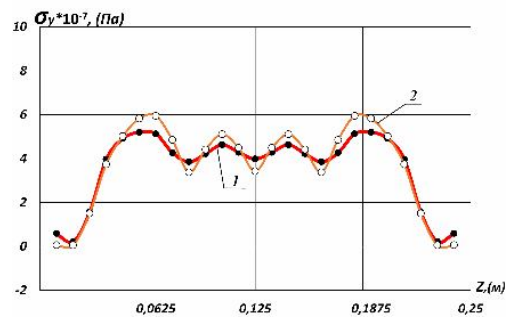

(b) $t=0.000225 \mathrm{~s}$

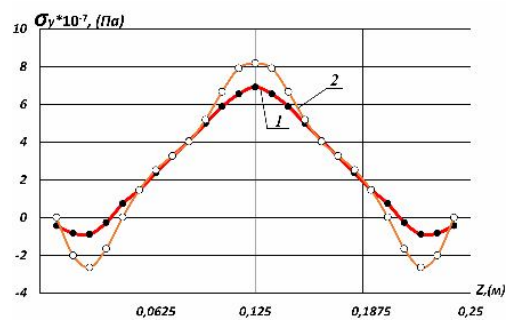

(c) $t=0.0004825 \mathrm{~s}$

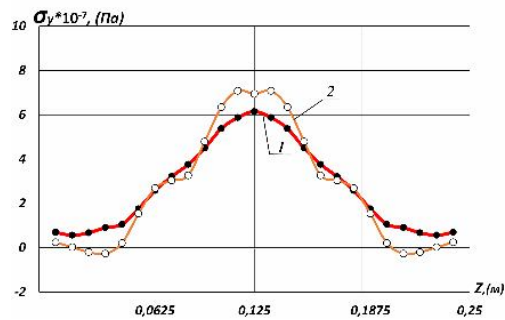

(d) $t=0.000465 \mathrm{~s}$

Fig. 2. Maximum stresses $\sigma_{y}$ of bearing layers of the shell

(1 - inner layer, 2 - outer layer) with different reinforcement options:

(a) provided correlation $E_{1} / E_{2}=500$ and 3-ribs reinforcement; (b) also for 5 ribs;

(c) provided correlation $\mathrm{E}_{1} / \mathrm{E}_{2}=50$ and 3-ribs reinforcement; (d) also for 5 ribs

Provided equal thicknesses of the inner and outer sheeting and equal intensity of the polymeric filler's reinforcement, the external sheeting layer appears more stressed. At $E_{1,3} / E_{T}=50$, the maximal outer layer stresses exceed those of the inner layer by over $10 \%$.

\section{REFERENCES}

1. Gaidaichuk V.V., Kotenko K.E. Stress-strain state of a three-layer cylindrical shell under internal axisymmetric pulse load // Strength of Materials and Theory of Structures. - 2020. Issue. 105. - P. 145-151.

2. Lugovoi P. Z., Gaidaichuk V.V., Skosarenko Yu.V., Kotenko K.E. Napruzheno-deformovanyi stan trysharovykh tsylindrychnykh obolonok $\mathrm{z}$ armovanym lehkym zapovniuvachem pry nestatsionarnomu navantazhenni (Stress - strain state of the three-layer cylindrical shells with reinforced lightweight filler under nonstationary load) // International Applied Mechanics 2021, 57, № 4 - P. 1-14.

3. Kheirikhah MM, Khalili SMR, Fard KM Biaxial buckling analysis of soft-core composite sandwich plates using improved high-order theory// European Journal of MechanicsA/Solids- 2012, 56, № 1 - P. 54-66.

4. Lugovoi P. Z., Meish V. F., Meish Yu. A., Orlenko S. P. Dynamic Design of Compound Shell Structures of Revolution Under Nonstationary Loads //Intern. Appl. Mech. - 2020, 56, № 1 - P. 22-32.

5. Lugovoi P.Z., Meish V.F. Chislennoye modelirovaniye i raschet na prochnost' mnogosloyníkh obolochek pri impul'snom nagruzhenii (Numerical modeling and strength analysis of multilayer shells under pulsed loading) // Проблемы прочности - 2000, № 4 - С.86-96. 
Гайдайчук В.В., Котенко К.Е., Сніжко Н.А.

\section{ВПЛИВ КОНСТРУКЦІЙНО-ТЕХНОЛОГІЧНИХ ФАКТОРІВ І НЕСТАЦІОНАРНОГО НАВАНТАЖЕННЯ НА НАПРУЖЕНО-ДЕФОРМОВАНИЙ СТАН ТРИШАРОВОӤ ЦИЛІНДРИЧНОЇ ОБОЛОНКИ}

Наведено результати оцінки напружено-деформованого стану тришарової циліндричної оболонки при різних фізико-механічних характеристиках полімерного наповнювача. Визначено ефективність впливу на НДС армування полімерного наповнювача оболонки дискретними ребрами.

Ключові слова: тришарова циліндрична оболонка, напружено-деформований стан, полімерний наповнювач, ребра жорсткості, імпульсне осесиметричне навантаження, скінченно-елементна модель.

\section{Gaidaichuk V.V., Kotenko K.E., Snizhko N.A. \\ IMPACT OF ENGINEERING/TECHNOLOGY FACTORS AND TRANSIENT LOADS ON THE STRESS - STRAIN STATE OF A THREE-LAYER CYLINDRICAL SHELL}

An issue of a stress-strain state of a three-layer cylindrical shell under variable loads has been considered. Assessment results of a three-layer cylindrical shell stress-strain state with regard to the physical and mechanical characteristics of an aggregate polymer filler and its reinforcement intensity by means of the stiffening rings rigidly connected to the shell coating are presented in the article. Calculations have been performed using the software Nastran. Values of displacements and stresses have been calculated by applying the direct transient dynamic process algorithm. The time interval was $0.0000025 \mathrm{sec}$, and the total number of steps was 200 . Choice of the three-dimensional finite element type was conditioned by the need of acquiring more detailed and accurate calculation results. The finite element model included 8000 three-dimensional solid finite elements and 9360 nodes. Impact of the physical and mechanical characteristics' parameters of integral polymeric filler through the stiffening rings on the shell's stress-strain state under the axisymmetric inner impulse load has been investigated. Numerous results concerning dynamics of the three-layer structure, which have been obtained by the finite elements method, allow distinguishing the stress-strain state of a threelayered cylinder-type elastic structure at any moment within an analyzed time interval. Optimization of the shell design is recommended. Intensity of the polymeric filler reinforcement impacts considerably the stress-strain state of the shell, as well as its performance characteristics. Increasing the intensity of the shell's polymeric layer reinforcement decreases considerably the deformation of the shell's bearing layers. Comparison of the obtained results to the impact of other factors indicates the credibility of the approach used and that the unbiased information was received.

Key words: three-layer cylindrical shell, stress-strain state, polymer filler, stiffening ribs, pulse axisymmetric load, finite element model.

Гайдайчук В.В., Котенко К.Е., Снижко Н.А.

\section{ВЛИЯНИЕ КОНСТРУКЦИОННО-ТЕХНОЛОГИЧЕСКИХ ФАКТОРОВ И НЕСТАЦИОНАРНОЙ НАГРУЗКИ НА НАПРЯЖЕННО-ДЕФОРМИРОВАННОЕ СОСТОЯНИЕ ТРЕХСЛОЙНОЙ ЦИЛИНДРИЧЕСКОЙ ОБОЛОЧКИ}

Приведены результаты оценки напряженно-деформированного состояния трехслойной цилиндрической оболочки при разных разных физико-механических характеристиках полимерного наполнителя. Определена эффективность влияния на НДС армирования полимерного наполнителя оболочки дискретные ребрами.

Ключевые слова: трехслойная цилиндрическая оболочка, напряженно-деформированное состояние, полимерный наполнитель, ребра жесткости, импульсное Осесимметричная нагрузки, конечно-элементная модель.

\section{УДК 539.3}

Гайдайчук В.В., Котенко К.Е., Сніжко Н.А. Вплив конструкційно-технологічних факторів і нестаціонарного навантаження на напружено-деформований стан тришарової циліндричної оболонки // Опір матеріалів і теорія споруд: наук.-тех. збірн. - К.: КНУБА, 2021. - Вип. 107. - С. 281-287.

У статті приведено результати оиінки напружено-деформованого стану тришарової чиліндричної оболонки, враховуючі ї̈ структурну особливість, фізико-механічні характеристики иільного полімерного наповнювача, армованого дискретними ребрами. Рекомендується оптимізація конструкційного рішення оболонки.

Таб. 1. Іл. 2. Бібліогр. 5 назв. 


\section{UDC 539.3}

Gaidaichuk V.V., Kotenko K.E., Snizhko N.A. Impact of engineering/technology factors and transient loads on the stress - strain state of a three-layer cylindrical shell // Strength of Materials and Theory of Structures: Scientific-and-technical collected articles - Kyiv: KNUBA, 2021. - Issue 106. - P. 281-287.

The article presents the results of assessing the stress-strain state of a three-layer cylindrical shell provided the different parameters of the polymeric filler's physical and mechanical characteristics reinforced by the discrete stiffening ribs. The reinforcement intensity efficiency of the polymeric filler due to the discrete stiffening ribs on the stress-strain state has been determined.

Tabl. 1. Fig. 2. Ref. 5 names.

\section{УДК 539.3}

Гайдайчук В.В., Котенко К.Э., Сніжко Н.А. Влияние конструкционно-технологических факторов и нестационарной нагрузки на напряженно-деформированное состояние трехслойной цилиндрической оболочки // Сопротивление материалов и теория сооружений. -2021. - Вып. 107. - С. 281-287.

В статье приведены результаты оценки напряженно-деформированного состояния трехслойной иилиндрической оболочки, учитывающие ее структурную особенность, физикомеханические характеристики иельного полимерного наполнителя, армированного дискретными ребрами. Рекомендуется оптимизация конструкиионного решения оболочки. Табл. 1. Ил. 2. Библиогр. 5 назв.

Автор (вчена ступень, вчене звання, посада): доктор технічних наук, професор, завідувач кафедри теоретичної механіки Київського національного університету будівництва i архітектури Гайдайчук Віктор Васильович.

Адреса робоча: 03680 Украӥна, м. Київ, проспект Повітрофлотський, 31, к. 433, Київський начіональний університет будівничтва і архітектури, кафедра теоретичної механіки, Гайдайчуку Віктору Васильовичу.

Роб. тел. +380 (44) 241-55-72;

Моб. тел. +380 (97) 542-94-27;

e-mail: viktor_gaydaychuk@bigmir.net

ORCID ID: https://orcid.org/0000-0003-2059-7433

Автор (вчена ступень, вчене звання, посада): кандидат технічних наук, доцент кафедри теоретичної механіки Київського національного університету будівництва і архітектури Котенко Костянтин Едуардович.

Адреса робоча: 03680 Україна, м. Київ, проспект Повітрофлотський, 31, к. 433, Київський національний університет будівництва і архітектури, кафедра теоретичної механіки, Котенку Костянтину Едуардовичу.

Роб. тел. +380 (44) 241-55-72;

Моб. тел. +380 (95) 585-20-76;

e-mail:1969box@mail.ru

ORCID ID: https://orcid.org/0000-0002-3181-3819

Автор (вчена ступень, вчене звання, посада): кандидат технічних наук, доцент кафедри теоретичної механіки Київського національного університету будівництва і архітектури Сніжко Наталія Анатолї̈на.

Адреса робоча: 03680 Україна, м. Київ, проспект Повітрофлотський, 31, к. 433, Київський національний університет будівництва і архітектури, кафедра теоретичної механіки, Сніжко Наталії Анатоліївні.

Роб. тел. +380 (44) 241-55-72;

Моб. тел. +380 (63) 232-77-68;

e-mail: nata_snizhko@ukr.net

ORCID ID: https://orcid.org/0000-0001-8469-3294 